\title{
Intake of high levels of vitamin A and polyunsaturated fatty acids during different developmental periods modifies the expression of morphogenesis genes in European sea bass (Dicentrarchus labrax)
}

\author{
Laure A. N. Villeneuve ${ }^{1 *}$, Enric Gisbert ${ }^{2}$, Jacques Moriceau ${ }^{1}$, Chantal L. Cahu ${ }^{1}$ and José L. \\ Zambonino Infante ${ }^{1}$ \\ ${ }^{1}$ UMR1067, Nutrition Aquaculture Génomique, IFREMER, 29280 Plouzané, France \\ ${ }^{2}$ Centre d'Aqüicultura, Institut de Recerca i Tecnologia Agroalimentaries (IRTA), Aptat. Correus 200, 43540 Sant Carles de la \\ Ràpita, Tarragona, Spain
}

(Received 13 July 2005 - Revised 28 August 2005 - Accepted 8 November 2005)

\begin{abstract}
The effect of the feeding period on larval development was investigated in European sea bass larvae by considering the expression level of some genes involved in morphogenesis. Larvae were fed a control diet except during three different periods (period A: from 8 to $13 \mathrm{~d}$ post-hatching (dph); period B: from 13 to $18 \mathrm{dph}$; period C: from 18 to $23 \mathrm{dph}$ ) with two compound diets containing high levels of vitamin A or PUFA. European sea bass morphogenesis was affected by these two dietary nutrients during the early stages of development. The genes involved in morphogenesis could be modulated between 8 and $13 \mathrm{dph}$, and our results indicated that retinoids and fatty acids influenced two different molecular pathways that in turn implicated two different gene cascades, resulting in two different kinds of malformation. Hypervitaminosis A delayed development, reducing the number of vertebral segments and disturbing bone formation in the cephalic region. These malformations were correlated to an upregulation of retinoic acid receptor $\gamma$, retinoid X receptor (RXR) $\alpha$ and bone morphogenetic protein (BMP)4. An excess of PUFA accelerated the osteoblast differentiation process through the upregulation of $\mathrm{RXR} \alpha$ and BMP4, leading to a supernumerary vertebra. These results suggest that the composition of diets devoted to marine fish larvae has a particularly determining effect before $13 \mathrm{dph}$ on the subsequent development of larvae and juvenile fish.
\end{abstract}

Sea bass larvae: PUFA: Vitamin A: Morphogenesis: Retinoid pathway

During the first 3 weeks of life, marine fish larvae undergo major morphological and functional changes to acquire their adult features. From hatching until $7 \mathrm{~d}$ post-hatching (dph), the feeding of European sea bass larvae is endogenous. It then becomes mixed until resorption of the vitellus; this generally occurs around $13 \mathrm{dph}$. At this date, the secretory function of the exocrine pancreas is not fully operational, only becoming efficient around $18-20 \mathrm{dph}$. The maturational process of the pancreas is also characterized by a strong decrease in amylase activity between 13 and $20 \mathrm{dph}$ (Zambonino Infante \& Cahu, 2001). The maturation of intestinal cells is characterized by a decrease in cytosolic enzyme activity between 18 and $25 \mathrm{dph}$, whereas the activity of the brush border membrane enzymes increases. During this period of intense functional changes, a huge morphological transformation of the larvae occurs, in particular in the development of the neurocranium and the jaw, the segmentation of the vertebrae that becomes visible around $20 \mathrm{dph}$, and the settlement of the adult fins between day 27 and day 40 (Barnabé et al. 1976).
During the first weeks of development, the maturation processes of the gastrointestinal tract can be influenced by nutritional conditions. Several studies have recently demonstrated that the morphogenesis of marine fish larvae could be perturbed by inappropriate dietary levels of vitamin A (retinol; Haga et al. 2002; Villeneuve et al. 2005a) or PUFA (Cahu et al. 2003). Moreover, the induced skeletal malformations depended on the nutrient. In the case of hypervitaminosis A in European sea bass, Villeneuve et al. (2005a) showed that a high percentage of malformations were localized in the cephalic region, and this correlated with an abnormal increase in the level of expression of a nuclear receptor involved in the retinoid pathway, the retinoic acid receptor (RAR) $\gamma$. Another study (Villeneuve et al. 2005b) revealed that high dietary levels of marine phospholipids containing high levels of EPA and DHA induced deformities affecting the vertebral column that correlated with the decrease in retinoid $\mathrm{X}$ receptor $(\mathrm{RXR}) \alpha$, another retinoid pathway receptor capable of constituting heterodimers with fatty acid receptors, PPAR. Taken together, these results indicated that the cellular retinoid 
pathway mainly involved RAR, whereas the fatty acid pathway implicated the RXR. Furthermore, these two signalling pathways acted on different morphological areas through the action of the nuclear receptors.

Vitamin A and its active derivatives, the retinoids, play a key role in morphogenesis and cellular differentiation during vertebrate development (Ross et al. 2000). The major active derivative of vitamin $\mathrm{A}$ is retinoic acid, which exists in two active forms: 9-cis and all-trans retinoic acid. Its actions involve two different kinds of nuclear receptor - RAR and RXR - which usually exist in three subfamilies $(\alpha, \beta$ and $\gamma$; Ross et al. 2000). RXR bind to 9-cis retinoic acid, whereas RAR bind both to all-trans and 9-cis retinoic acid (Ross et al. 2000). These receptors can form dimers either together or with other receptors, such as thyroid hormone, vitamin D or fatty acid receptors (PPAR; Yu et al. 1991). These dimers have the ability to regulate the expression of their target genes. The retinoid pathway can act on more than 500 genes (Balmer \& Blomhoff, 2002) including the Hox genes, involved in tissue development and differentiation (Krumlauf, 1994; Suzuki et al. 1999), bone morphogenetic protein (BMP; Thompson et al. 2003) and insulin-like growth factor (Gabbitas \& Canalis, 1997). BMP and insulin-like growth factor are implicated in skeletal patterning, bone development and limb morphogenesis. BMP are multifunctional regulators of vertebrate development: they regulate cell proliferation, differentiation, morphogenesis and apoptosis (Hogan, 1996). Insulinlike growth factor $-\mathrm{I}$ is a mitotic agent that acts as a growth promoter and as a differentiation factor in bone, muscle and cartilage (Zizola et al. 2002). Many studies have demonstrated that inadequate dietary levels of vitamin A lead to the appearance of skeletal malformations (Haga et al. 2002, 2003; Villeneuve et al. 2005a).

In fish nutrition, lipids are the major energy source (Sargent et al. 1999), and as fish are unable to synthesize de novo $n-3$ PUFA, they have to find them in their food. It has recently been demonstrated that these PUFA, particularly EPA and DHA, are more efficiently used by marine fish when present in the phospholipid fraction of the diet (Gisbert et al. 2005). Fatty acids are natural ligands for PPAR, which play a key role in lipid metabolism and energy balance. As mentioned earlier, PPAR and RXR can dimerize to regulate the target genes involved in these two signalling pathways (Keller et al. 1993). This underlines the key role of RXR in several pathways, and, as a consequence, any perturbation of the expression of the RXR may have repercussions on these pathways.

Many genes involved in development processes, including Hox genes, have been intensively studied, and some of them are expressed in defined spatio-temporal windows (Krumlauf, 1994). Nevertheless, few studies have investigated interactions between exogenous nutrition and the genes involved in morphogenesis. It has been shown that an excess of vitamin A can have negative effects on fish morphogenesis, but in this case the excess of vitamin A was present in the tank water (balneation) but not directly in the diet (Suzuki et al. 2000). We previously demonstrated that diets containing a high level of vitamin A or phospholipids disturbed developmental processes when ingested by European sea bass larvae between day 7 and day 40. In the present study, our goal was to determine whether these effects appeared when larvae were fed these diets at a particular developmental stage. To check this, we considered three different periods of larval life.

\section{Materials and methods}

\section{Animals and diets}

Three-day-old European sea bass (Dicentrarchus labrax) larvae were obtained from the Ecloserie Marine de Gravelines (Gravelines, France) and shipped to the Fish Nutrition Laboratory at Ifremer (Centre de Brest). Fish were acclimated and divided into twenty-one 35 litre-cylindroconical fibreglass tanks (2100 larvae/tank) at a initial density of 60 larvae/l. Tanks were supplied with running sea water, which had been previously passed through a sand filter, followed by a tungsten heater and a degassing column packed with plastic rings. Throughout the experiment, water temperature and salinity were kept at $20^{\circ} \mathrm{C}$ and $35 \mathrm{~g} / \mathrm{l}$, respectively, and the oxygen level was maintained above $6 \mathrm{mg} / \mathrm{l}$ by setting the water exchange of the tank at $30 \% / \mathrm{h}$ (flow rate $0 \cdot 18 \mathrm{l} / \mathrm{min}$ ). The photoperiod was $24 \mathrm{~h}$ light $/ 0 \mathrm{~h}$ dark, and maximum light intensity was $9 \mathrm{~W} / \mathrm{m}^{2}$ at the water surface. All animal procedures and handling were conducted in compliance with the Guide for the Care and Use of Laboratory Animal (National Research Council, 1985).

Four days after hatching, larvae were divided into seven experimental groups (three replicates per group) that were fed three isonitrogenous and isolipidic experimental compound microdiets from the onset of exogenous feeding at $7 \mathrm{dph}$. The control diet contained $0.08 \mathrm{~g} / \mathrm{kg}$ vitamin A (Sigma R3250, 500 $000 \mathrm{IU} / \mathrm{g}$; Sigma, St Louis, MO, USA) and $175 \mathrm{~g} / \mathrm{kg}$ soyabean lecithin, whereas the high-vitamin-A (RA) diet contained $32 \mathrm{~g} /$ $\mathrm{kg}$ retinol (Table 1). Although the phospholipid content of the experimental diets was similar, the diets differed in their respective sources of this nutrient: marine phospholipid (MP) in the MP diet and soyabean lecithin in the RA diet. The composition of the control diet was very similar to the one previously used and that had supported good growth and survival in European sea bass larvae (Villeneuve et al. 2004). In order to evaluate the ontogenetic effect of the diet on larval morphogenesis, fish were fed the RA and MP diets at three different developmental periods (Fig. 1): $8-13$ dph (abbreviated as RA-A and MP-A), 13$18 \mathrm{dph}$ (RA-B and MP-B) and 18-23 dph (RA-C and MP-C). Apart from the afore-mentioned intervals, larvae were fed the control diet. The control group was fed the control diet throughout the experimental time. Microdiets were prepared as previously described (Cahu et al. 2003), and the pellet size was 200-400 $\mu \mathrm{m}$. Throughout the experimental period, larvae were continuously fed in large excess for $24 \mathrm{~h} / \mathrm{d}$ using automatic belt-feeders. Food ingestion was monitored by observing larval digestive tracts under a binocular microscope, dietary microparticles being visible as transparency.

\section{Sampling}

To evaluate larval growth, ten specimens were randomly sampled from each experimental tank (thirty larvae per experimental diet) at 25 and $37 \mathrm{dph}$. They were killed with an overdose of anaesthetic (tricaine methanesulfonate, Sigma A5040), and their wet body weight was measured to the nearest $0.1 \mathrm{mg}$. Larvae (20-50 larvae, depending on wet body weight) were 
Table 1. Composition of the experimental compound diets

\begin{tabular}{lccc}
\hline Ingredients & Con & RA & MP \\
\hline Fish meal* $^{*}$ & 555 & 555 & 555 \\
Hydrolysed fish meal (CPSP)* $^{*}$ & 140 & 140 & 140 \\
Soyabean lecithin* $^{*}$ Marine lecithin* & 175 & 175 & 0 \\
Vitamin mixture (without RA)† $_{\text {Mineral mixtureł }}$ & 0 & 0 & 175 \\
Betaine & 40 & 80 & 80 \\
Retinol (all-trans) & 10 & 40 & 40 \\
Analysed composition & $0 \cdot 08$ & 10 & 10 \\
Proteins (N $\times 6 \cdot 25)$ & & 32 & 0.08 \\
Lipids & 56 & $\%$ & \\
Containing: & 19 & 19 & 59 \\
$\quad$ Phospholipids & 13 & 13 & 17 \\
$\quad$ EPA + DHA & $1 \cdot 1$ & $1 \cdot 1$ & 13 \\
Ash & 15 & 15 & 15 \\
DM & 94 & 94 & 94 \\
Energy (J/kg) & 1651 & 1651 & 1626 \\
\hline
\end{tabular}

Con, control diet; RA, high-vitamin-A diet; MP, marine phospholipid diet.

${ }^{*}$ All dietary ingredients were commercially obtained. Fish meal (La Lorientaise,

Lorient, France); hydrolysed fish meal (CPSP, Soluble Fish Protein Concentrate; Sopropêche, Boulogne sur Mer, France); cod liver oil (La Lorientaise); marine lecithin (LC60, Phosphomins; Phosphotech, Saint Herblain, France); soya lecithin (Ets Louis François, St Maur des Fossés, France).

†Per kg vitamin mixture: choline concentrate $50 \% 200 \mathrm{~g}$, vitamin E $(500 \mathrm{Ul} / \mathrm{g}) 10 \mathrm{~g}$ vitamin $D_{3}(500,000 \mathrm{Ul} / \mathrm{g}) 500 \mathrm{mg}$, vitamin $B_{3} 1 \mathrm{~g}$, vitamin $B_{5} 2 \mathrm{~g}$, vitamin $B_{1}$ $100 \mathrm{mg}$, vitamin $B_{2} 400 \mathrm{mg}$, vitamin $B_{6} 300 \mathrm{mg}$, vitamin $C 20 \mathrm{~g}$, vitamin $B_{9}$ $100 \mathrm{mg}$, vitamin concentrate $B_{12}(1 \mathrm{~g} / \mathrm{kg}) 1 \mathrm{~g}$, biotin $1 \mathrm{~g}$, vitamin $\mathrm{K}_{3} 1 \mathrm{~g}$, meso-inositol $30 \mathrm{~g}$, cellulose $732.1 \mathrm{~g}$.

$\ddagger$ Per kg mineral mixture: $\mathrm{KCl} 90 \mathrm{~g}, \mathrm{KIO}_{4} 40 \mathrm{mg}, \mathrm{CaHPO}_{4} 2 \mathrm{H}_{2} \mathrm{O} 500 \mathrm{~g}, \mathrm{NaCl} 40 \mathrm{~g}$ $\mathrm{CuSO}_{4} 5 \mathrm{H}_{2} \mathrm{O} 3 \mathrm{~g}, \mathrm{ZnSO}_{4} 7 \mathrm{H}_{2} \mathrm{O} 4 \mathrm{~g}, \mathrm{CoSO}_{4} 7 \mathrm{H}_{2} \mathrm{O} 20 \mathrm{mg}, \mathrm{FeSO}_{4} 7 \mathrm{H}_{2} \mathrm{O} 20 \mathrm{~g}$ $\mathrm{MnSO}_{4} \mathrm{H}_{2} \mathrm{O} 3 \mathrm{~g}, \mathrm{CaCO}_{3} 215 \mathrm{~g}, \mathrm{MgSO}_{4} 7 \mathrm{H}_{2} \mathrm{O} 124 \mathrm{~g}, \mathrm{NaF} 1 \mathrm{~g}$.

For details of diets and procedures, see p. 678.

sampled from each tank at $25 \mathrm{dph}$ and kept at $-20^{\circ} \mathrm{C}$ pending assays of pancreatic (trypsin EC (3.4.21.4) and amylase (EC 3.2.1.1)) and brush border intestinal enzymes (alkaline phosphatase (EC 3.1.3.1)), which are indicators of the maturation level of the digestive tract. Fifty larvae were collected for mRNA studies from all experimental tanks at 13, 16, 25 and $37 \mathrm{dph}$, and total RNA was immediately extracted. In all cases, sampling procedures were performed as previously described (Cahu et al. 2003). The incidence of body skeletal malformations (splachnocranium, neurocranium and vertebral column deformities) was counted at $37 \mathrm{dph}$ (100 larvae per experimental diet). A complete description of each malformation typology has been previously described in Villeneuve et al. (2004), and head abnormalities are summarized in Fig. 2. Repetitive sampling made it impossible to calculate larval survival.

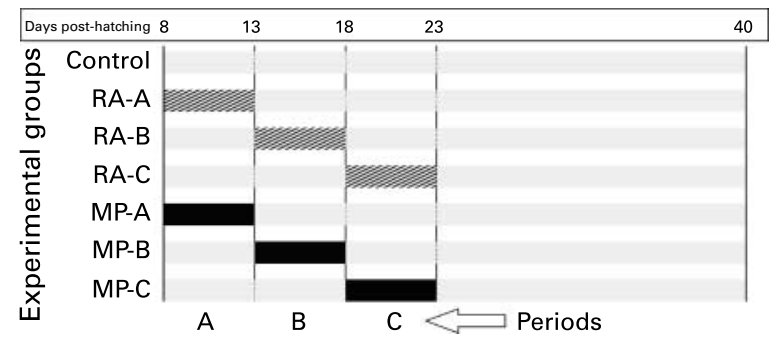

Fig. 1. Schema of the distribution of control, high-vitamin-A (RA) and marine phospholipid (MP) diets. For details of diets and procedures, see p. 678 , Control;, RA; $\mathbf{\square}, \mathrm{MP}$.
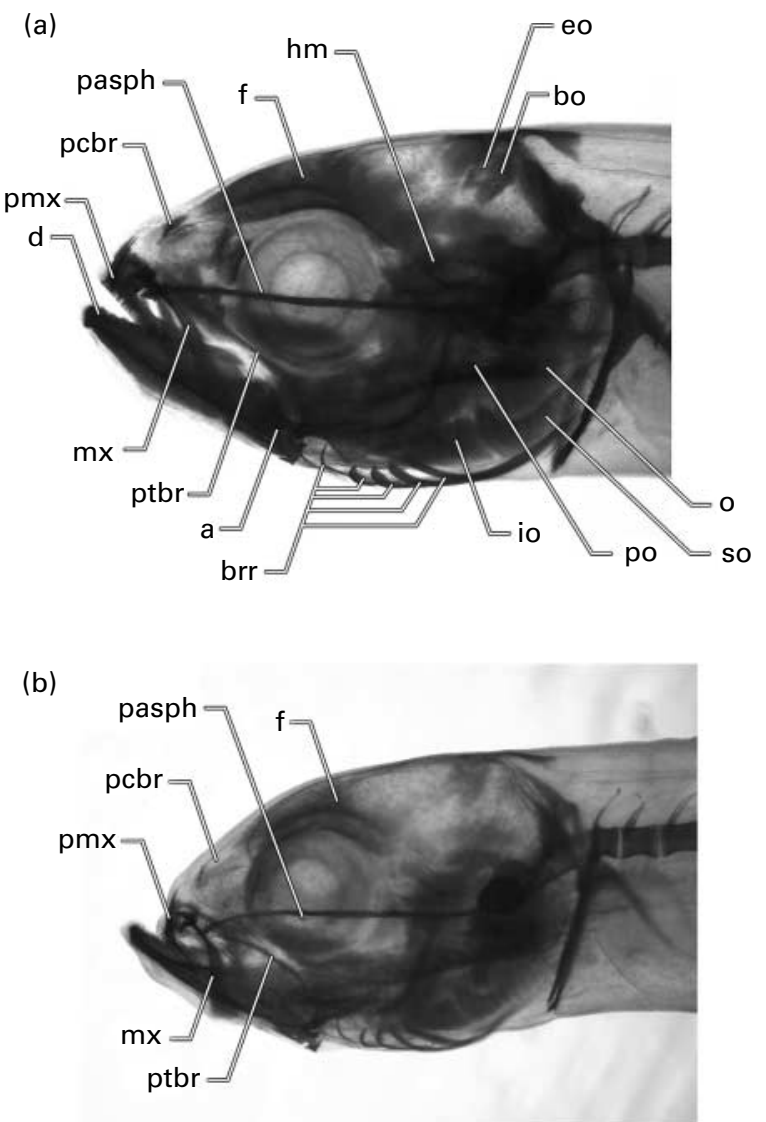

Fig. 2. Dietary induced malformations in the cranium of European sea bass larvae (age $40 \mathrm{~d}$ post-hatching). (a) Normal larvae. (b) Deformed larvae (abnormal structures are indicated). Specimens were stained with Alizarin red to reveal calcified structures. a, angular; bbr, branchiostegal rays; bo, basioccipital; $d$, dentary; eo, exoccipital; $f$, frontal; $h m$, hyomandibula; io, interoperculum; $m x$, maxilla; $o$, operculum; pasph, parasphenoid; $p c b r$, lamina paracerebralis; $p m x$, premaxilla; $p o$, preoperculum; ptbr, pterygoid process; so, suboperculum.

\section{Analytical methods}

Larvae were dissected under a binocular microscope on a glass cutting-board kept on ice $\left(0^{\circ} \mathrm{C}\right)$. Individuals were cut into four parts - head, pancreatic segment, intestinal segment and tail in order to limit the assay of enzymes to specific segments. This dissection inevitably produced a crude mixture of organs in each segment. The pancreatic segment contained the pancreas, liver, heart, muscle and spine. The intestinal segments were homogenized in 30 volumes (v/w) mannitol $(50 \mathrm{~mm})$ Tris- $\mathrm{HCl}(2 \mathrm{~mm}), \mathrm{pH} 7$, and contained the intestine, muscle and neural spine (Zambonino Infante et al. 1997). Once dissected, the pancreatic segments were homogenized in 5 volumes $(\mathrm{v} / \mathrm{w})$ ice-cold distilled water.

Trypsin and amylase activities were measured using Nabenzoyl-DL-arginine- $p$-nitroaniline and starch, respectively, as substrate (Métais \& Bieth, 1968; Holm et al. 1988) in both the pancreatic and intestinal segments. Purified brush border membranes from the intestinal segment were obtained according to a method developed for intestinal scraping (Crane et al. 1979). Alkaline phosphatase, an enzyme of the intestinal brush border membrane, was quantified using p-nitrophenylphosphate as substrate (Bessey et al. 1946). 
The degree of purification of the brush border membrane, considering alkaline phosphatase as a marker for the cell membrane fraction, was close to that reported in the literature (i.e. 11.0; Crane et al. 1979). Pancreatic and intestinal specific enzyme activities were expressed as $\mu \mathrm{mol}$ substrate hydrolysed per min and per $\mathrm{mg}$ protein (U/mg protein), protein being determined using the Bradford method (Bradford, 1976). Secretions of trypsin and amylase were calculated as a ratio of activity in the intestinal segment related to total activity (pancreatic segment plus intestinal segment), considering that enzyme activity in the pancreatic segment can be used as an index of the synthetic function of pancreas, and in the intestinal segment as an index of pancreatic secretory function (Péres et al. 1998).

The protein concentration of the three diets was assayed following the Dumas method (Nitrogen Analyser 2000, Fisons Instruments, $\mathrm{N} \times 6.25$; Carlo Erba, Milan, Italy).

Total lipids in the diets were determined according to a slightly modified version of Folch's procedure (Folch et al. 1957), chloroform being replaced by dichloromethane. The separation of neutral lipids and phospholipids was carried out according to the procedure described by Juaneda \& Rocquelin (1985). Fatty acids were saponified by a $2 \mathrm{M}-\mathrm{KOH}-$ methanol solution and then esterified in a $0.7 \mathrm{M}-\mathrm{HCl}-m e t h a n o l$ solution. Fatty acid methyl esters were separated by GC, in an Auto-system Perkin-Elmer (Wellesley, MA, USA) with a flame ionization detector, BPX 70 capillary column $(25 \mathrm{~m} \times 0.22 \mathrm{~mm}$ internal diameter $\times 0.25 \mu \mathrm{m}$ film thickness $)$ and split-splitless injector, with $\mathrm{He}$ as the carrier gas. The injector and detector temperatures were $220^{\circ} \mathrm{C}$ and $260^{\circ} \mathrm{C}$, respectively. The initial oven temperature was $50^{\circ} \mathrm{C}$, but this was increased to $180^{\circ} \mathrm{C}$ by increments of $15^{\circ} \mathrm{C} / \mathrm{min}$, maintained for $5 \mathrm{~min}$ and finally increased to $220^{\circ} \mathrm{C}$ by increments of $3^{\circ} \mathrm{C} / \mathrm{min}$. Data acquisition and handling were carried out by connecting the gas chromatograph to a Nelson computer (Perkin-Elmer). The individual fatty acid methyl esters were identified by comparing the retention times of authentic standard mixtures and the results of individual fatty acid compositions were expressed as percentages of the total identified fatty acid methyl esters in the phospholipid and neutral lipid fractions.

\section{RT-PCR analysis}

Different complementary DNA (cDNA) fragments from genes coding for RAR and for signalling molecules known to interact with retinoic acid were purified in European sea bass larvae by RT-PCR, cloned (Cahu et al. 2003), sequenced and registered by the European Molecular Biology Laboratory: RXR $\alpha$; accession number AJ 567907, RAR $\alpha$; AJ 496189, RAR $\gamma$; AJ 496181, BMP-4; AJ 567451 and insulinlike growth factor-I (AJ 579342). Glyceraldehyde-3-phosphate deshydrogenase (GAPDH; AJ 567450) was chosen as the housekeeping gene.

\section{Real-time RT-PCR}

cDNA samples were treated with DNase, and real-time PCR was performed using the iCycler iQ (Bio-Rad Laboratories Inc., Hercules, CA, USA). Quantitative PCR analyses for each gene were performed in a total volume of $15 \mu \mathrm{l}$ containing $5 \mu \mathrm{l}$ cDNA $\left(10^{-3}\right.$ dilution), $1.5 \mu \mathrm{l}$ fluorescein ( $100 \mathrm{nmol} / \mathrm{l}$; Bio-Rad), $0.5 \mu \mathrm{l}$ primers $(10 \mu \mathrm{mol} / \mathrm{l})$ and $7.5 \mu \mathrm{l}$ QuantiTect SYBR Green PCR Master Mix 2X (QIAGEN $\mathrm{GmbH}$, Hilden Germany). For each target gene, forward and reverse primers (Villeneuve et al. 2004) were chosen from the sequences previously cloned. Thermal cycling was initiated with incubation at $95^{\circ} \mathrm{C}$ for $13.5 \mathrm{~min}$ in order to activate HotStarTaq DNA polymerase (Qiagen). After this initial step, forty-five cycles of PCR were performed. Each PCR cycle consisted of heating for $30 \mathrm{~s}$ at $95^{\circ} \mathrm{C}$ for denaturing, and then for $1 \mathrm{~min}$ at $60^{\circ} \mathrm{C}$ for annealing and extension. Cycle threshold (CT) values corresponded to the number of cycles at which the fluorescence emission monitored in real time exceeded the threshold limit.

Melting curve analysis was performed to confirm the production of a single product in these reactions, and these products were sequenced by MilleGen (Labège, France). Standard curves were established for each gene by plotting CT values against the $\log _{10}$ of five different dilutions (in triplicate) of cDNA sample solutions. Real-time PCR efficiency was determined for each gene from the slopes given by BIORAD software, applying the equation $E=10^{[-1 / \text { slope }]}$. We calculated the relative expression ratio of each gene using REST software (http://www.gene-quantification.info/). The relative expression ratio for a considered gene is based on the PCR efficiency (E) and CT of a sample compared with the control, and expressed in comparison to the reference gene (GAPDH), according to Pfaffl's mathematical model (Pfaff, 2001):

$$
\begin{aligned}
\text { Ratio }= & {\left.\left[\mathrm{E}_{\text {gene }}\right)^{\Delta \mathrm{CTgene}(\text { control-sample })}\right] } \\
& /\left[\left(\mathrm{Ef}_{\mathrm{GAPDH}}\right)^{\Delta \mathrm{CTGAPDH}(\text { control-sample })}\right]
\end{aligned}
$$

Normalization relative to GAPDH provided a widely applicable value for comparative studies of gene expression at the mRNA level, as its expression is constant during the activation and proliferation of cells (Gause \& Adamovicz, 1994).

\section{Statistical analyses}

Results are given as means and standard deviations. All data were checked for variance homogeneity using Barlett's test (Dagnelie, 1975). Growth, enzymatic specific activity and arc$\sin \left(\mathrm{x}^{1 / 2}\right)$-transformed trypsin and amylase secretions were compared by means of one-way ANOVA followed by a Newman Keuls multiple range test when significant differences were detected $(P<0 \cdot 05)$. Statistical differences in gene expression between the control and samples were evaluated in group means by randomization tests (Pfaffl et al. 2002) using REST software. Two thousand random allocations were performed and differences were considered to be significant at $\mathrm{P}=0 \cdot 05$.

\section{Results}

Growth

At 25 dph, larvae fed the control diet exhibited the best growth (Fig. 3). Whatever the feeding period, the weight of larvae fed the MP diet was significantly greater than that of larvae fed the RA diet. Globally, the more the larvae were fed the diet in the early stages, the less they grew (MP-C $>$ MP-B $>$ MP-A). 


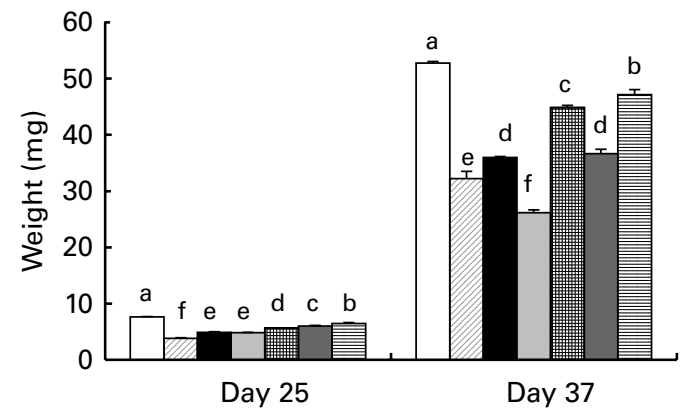

Fig. 3. Growth at 25 and 37 days post-hatching of European sea bass larvae fed isonitrogenous and isolipidic diets containing a high level of vitamin A (RA diet), a high level of marine phospholipids (MP diet) or the control diet, according to the feeding periods. Means and standard deviations ( $n 3)$.

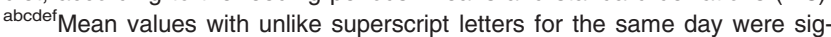
nificantly different $(P<0.05)$. Fish were fed the high vitamin $\mathrm{A}(\mathrm{RA})$ diet and marine phospholipids (MP) diet at three different developmental periods: RAA, MP-A, 8-13d post hatching (dph); RA-B, MP-B, 13-18 dph; RA-C, MPC, $18-23 \mathrm{dph}$. For details of diets and procedures, see p. 678. $\square$, control;

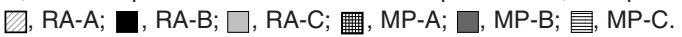

At $37 \mathrm{dph}$, the control group still exhibited the best growth (52.8 (SD 0.26) $\mathrm{mg}$ ), and fish fed MP diets were still heavier than those fed RA diets over the same period. In the experimental groups fed RA diets, the best growth was observed in the RA-B group (36 (SD 0.17) $\mathrm{mg}$ ) and the lowest growth in the RA-C group (26.1 (SD 0.52) $\mathrm{mg}$ ), the RA-A group exhibiting intermediate growth (32.2 (SD 1.26) $\mathrm{mg} ; P<0.05)$. In the MP groups, the greatest growth was obtained in the MP-C group (47.2 (SD 0.9) $\mathrm{mg}$ ) and the least in the MP-B group (36.6 (SD 0.76) mg), intermediate growth being observed in the MP-A group (44.9 (SD $0.35) \mathrm{mg} ; P<0.05)$.

Skeletal malformations. The number of vertebrae most frequently observed in European sea bass larvae is twenty-five. The six experimental groups fed on the RA or MP diets contained individuals with twenty-six or twentyfour vertebrae instead.

In the MP-A group, $3 \%$ of the larvae exhibited twenty-three vertebrae, but this was not significantly different $(P=0.413)$ from the findings for other groups.

The RA diet $(F$ 21.12, $P=0.001)$ and feeding period ( $F$ 8.76, $P=0.006$ ) effects were evidenced in fish with twenty-four vertebrae. The RA diet induced the loss of a vertebra during period A. No significant difference was observed when this diet was applied during periods B and C (Fig. 4).

MP diet $(F 17.79, P=0.002)$ and feeding period $(F 17.25$, $P=0.0006)$ effects were also observed in larvae with twenty-six vertebrae. The number of vertebrae significantly increased in association with the MP diet $(P<0.005)$, and this effect was apparent only when the diet was ingested during period A ( $P \leq 0 \cdot 0001$; Fig. 4).

The number of fish exhibiting jaw malformations depended on the diet $(F 16.96, P=0.003)$ but not on the feeding period. At $40 \mathrm{dph}, 4-8 \%$ of larvae exhibited jaw deformities in the control and MP groups. The rate of these deformities was significantly higher in the experimental groups fed the RA diets $(P<0.05)$ regardless of the period.

The rate of malformation in the vertebral column region (e.g. scoliosis, lordosis, vertebrae fusion) depended on both

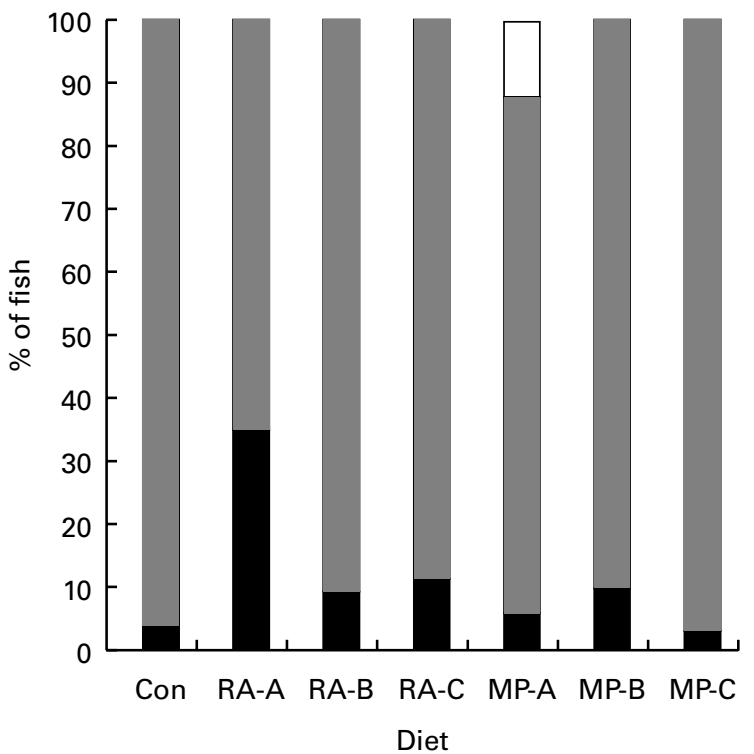

Fig. 4. Percentage of vertebral number in European sea bass larvae at $37 d$ post-hatching. Fish were fed the high vitamin A (RA) diet and marine phospholipids (MP) diet at three different developmental periods: RA-A, MP-A, 8$13 \mathrm{~d}$ post hatching (dph); RA-B, MP-B, 13-18 dph; RA-C, MP-C, 18-23 dph. For details of diets and procedures, see p. 678. $\square, 26$ Vertebrae; $\square, 25$ Vertebrae; $\square$, 24 Vertebrae. Con, control.

the diet $(F$ 40.83, $P=0.0001)$ and the feeding period ( $F$ 15.54, $P=0.001)$. This rate was significantly higher in fish fed the MP diet $(P=0.0003)$ during periods A $(P<0.02)$ and $\mathrm{B}(P<0.009)$, respectively, affecting $20 \%$ and $29 \%$ of the total number of fish on day 40. At the same age, only $6-19 \%$ of larvae fed on either the control or the RA diet exhibited vertebral deformities.

Enzymatic activities and secretion rate. Specific activities and secretion rates were determined at $25 \mathrm{dph}$.

The highest specific activity of alkaline phosphatase was measured in the control group (1192 (SD 170.2) mU/mg protein; Fig. 5). There was no statistically difference between

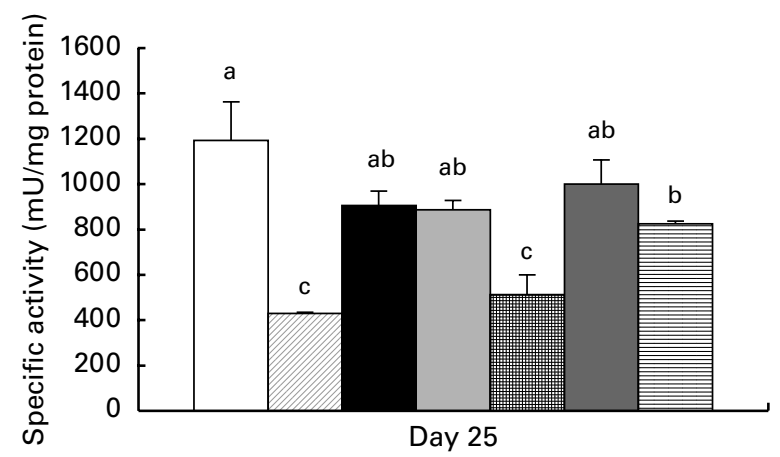

Fig. 5. Specific activity of alkaline phosphatase of the intestinal brush border in European sea bass at $25 \mathrm{~d}$ post-hatching. Means and standard deviations

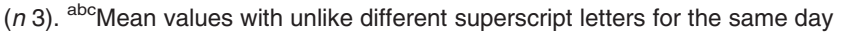
were significantly different $(P<0 \cdot 05)$. Fish were fed the high vitamin A (RA) diet and marine phospholipids (MP) diet at three different developmental periods: RA-A, MP-A, 8-13 d post hatching (dph); RA-B, MP-B, 13-18 dph; RA-C, MP-C, 18-23 dph. For details of diets and procedures, see p. 678. $\square$,

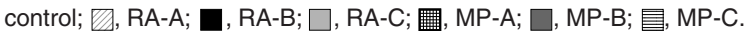


the control, RA-B, RA-C and MP-B groups. This specific activity was $64 \%$ lower in the RA-A group (429 (SD 5.7) $\mathrm{mU} / \mathrm{mg}$ protein) and $57 \%$ lower in the MP-A group (512 (SD 88.4 ) $\mathrm{mU} / \mathrm{mg}$ protein).

The specific activity of amylase did not significantly differ between the control, RA-C and MP-C groups. This activity was significantly higher (Fig. 6) in the other four experimental groups.

The highest values for amylase secretion rate were observed in the control group (Fig. 7a) and in the MP-A, MP-C and RAC groups (77.5 (SD 6.36) \%, 75.3 (SD 2.52) \%, 77 (SD 4.24) \% and 84.3 (SD 4.04) \%, respectively). The lowest values were measured in fish fed on MP-B and RA-A (50.7 (SD 4.73) \% and 53.5 (SD $0.71 \%$ ), respectively; $P<0.05$ ). The RA-B group exhibited an intermediate value. The trypsin secretion profile was comparable to that of amylase (Fig. 7b).

Gene expression. Variations in gene transcription are reported in Table 2 Significant variations during periods A and $\mathrm{B}$ are emphasized in Fig. 8, which shows that the variations in $\operatorname{RXR} \alpha$ transcription observed at $18 \mathrm{dph}$ (regardless of the feeding period) and in BMP4 transcription at $13 \mathrm{dph}$ for period A were linked to the developmental stage of the larvae, whereas the other variations were induced by the diets.

At $13 \mathrm{dph}$ in the RA-A group, RAR $\gamma$ and BMP4 transcriptions were significantly higher (transcription factor 2.77 -fold $(P<0.03)$ and 2.84 -fold $(P<0.003)$, respectively) than in the control group. BMP4 transcription was also higher in the MP-A group (transcription factor 2.34-fold; $P<0.03)$, whereas RAR $\gamma$ transcription was not modified $(P=0.08)$.

At $18 \mathrm{dph}, \mathrm{RXR} \alpha$ transcription was positively regulated in the RA-A and MP-A groups (respective transcription factors 2.88 -fold and 1.85 -fold; $P<0.001$ ). In the RA-B group, $\mathrm{RXR} \alpha$ transcription was 3.5 times greater than in the control group. In fish fed the MP diet during period A, BMP4 transcription was 1.8 times lower $(P<0.001)$. In fish fed on MP during period $\mathrm{C}$, the transcription levels for $\mathrm{RAR} \alpha$, BMP4 and insulin-like growth factor -I were significantly lower

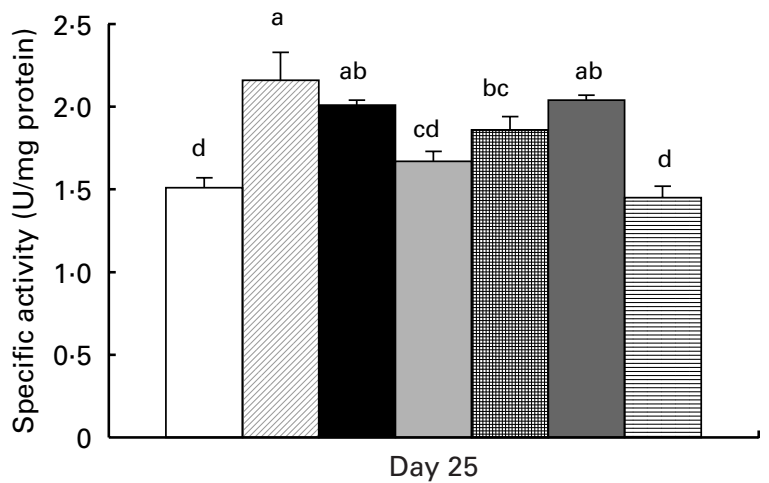

Fig. 6. Specific activity of amylase in European sea bass at $25 \mathrm{~d}$ post-hatching. Means and standard deviations $(n 3) .{ }^{\text {abcd }}$ Mean values with unlike different superscript letters for the same day were significantly different $(P<0.05)$. Fish were fed the high vitamin $A(R A)$ diet and marine phospholipids (MP) diet at three different developmental periods: RA-A, MP-A, 8-13 d post hatching (dph); RA-B, MP-B, 13-18 dph; RA-C, MP-C, 18-23 dph. For details of diets and procedures, see p. 678. $\square$, control; $\square$, RA-A; $\square$, RA-B;

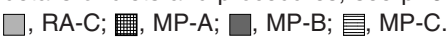
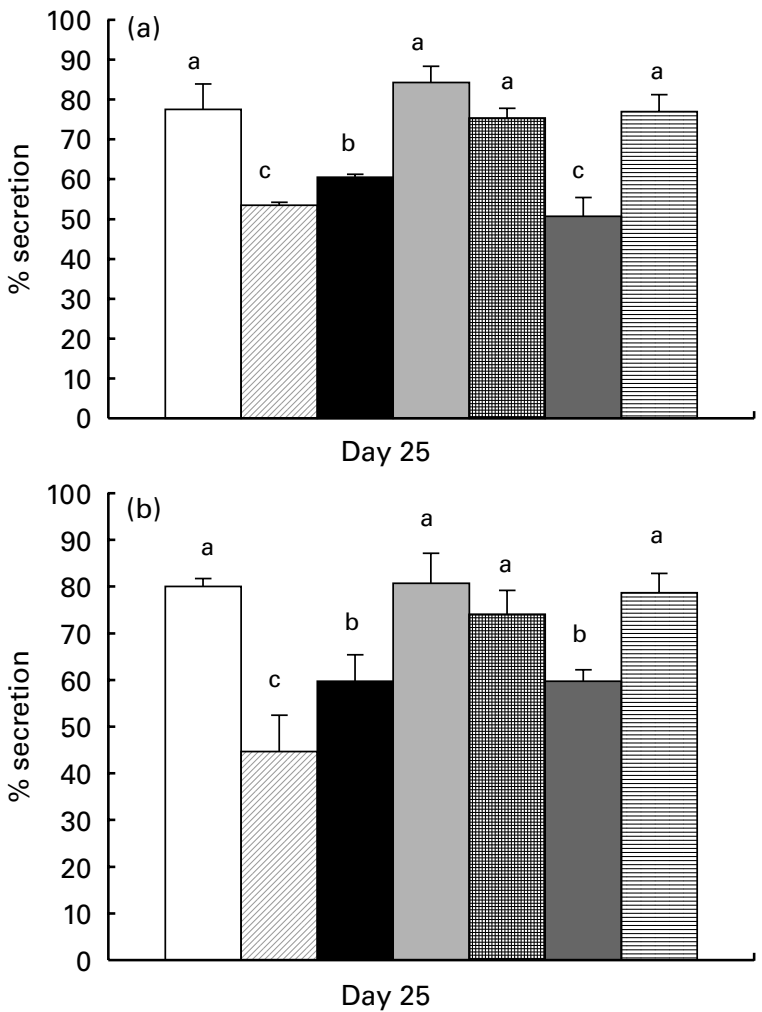

Fig. 7. Secretion rate of amylase (a) and trypsin (b) in European sea bass larvae at $25 \mathrm{~d}$ post-hatching. Means and standard deviations $(n 3) .{ }^{\mathrm{abc}}$ Mean values with unlike different superscript letters for the same day were significantly different $(P<0.05)$. Fish were fed the high vitamin $A(R A)$ diet and marine phospholipids (MP) diet at three different developmental periods: RAA, MP-A, 8-13 d post hatching (dph); RA-B, MP-B, 13-18 dph; RA-C, MPC, $18-23 \mathrm{dph}$. For details of diets and procedures, see p. 678 . $\square$, control; 囚, RA-A; $\square$, RA-B; $\square$, RA-C; 嘈, MP-A; $\square$, MP-B; 冒, MP-C.

(respective transcription factors $1 / 3.51,1 / 1.26$ and 1/3.43; $P<0.001)$.

At $23 \mathrm{dph}$ in the RA-A experimental group, BMP4 transcription was 1.5 times higher, whereas in the RA-B group, $\mathrm{RAR} \gamma, \mathrm{RXR} \alpha$ and BMP4 transcription was, respectively, $1.96,1.94$ and 2.64 times $(P<0.001)$ lower than in the control group. In fish fed MP-B, BMP4 transcription was 2.1 times less $(P<0.001)$. In fish fed MP-C, RAR $\gamma$ transcription increased (transcription factor 1.96-fold; $P<0.03$ ), whereas $\mathrm{RXR} \alpha$ transcription decreased (transcription factor 2.3; $P<0.03)$. At this date, the MP diet had no noticeable effect when ingested during period A.

At the end of the rearing period ( $40 \mathrm{dph}$ ), RAR $\alpha, \operatorname{RAR} \gamma$ and BMP4 transcription was significantly higher in group RA-A than in the controls (respective transcription factors 3.39fold $(P<0.002) ; \quad 3.25$-fold $(P<0.001)$ and 2.08 -fold $(P<0.02))$. Increases of $2.42,2.99,3.82$ and 7.89 -fold in RAR $\alpha$ transcription were respectively observed for the MPA $(P<0.001)$, RA-B $(P<0.001)$, RA-C $(P<0.001)$ and MP$\mathrm{B}(P<0.001)$ groups with regard to the control group. In fish fed MP-B, the transcription of RAR $\gamma, \mathrm{RXR} \alpha$ and BMP4 was also enhanced (respective transcription factor 3.15-fold, 3.58 -fold and 3.44-fold; $P<0.001$ ). At this date, there was no variation in gene expression in the MP-C group with regard to the control. 
Table 2. Variations in gene transcription level during periods $A$ (8-13 d post-hatching; dph), B (13-18 dph) and $C(18-23 \mathrm{dph})$ in larvae fed high-vitamin-A (RA) or marine phospholipid (MP) diets, in comparison to the control group

\begin{tabular}{|c|c|c|c|c|c|c|c|}
\hline \multirow{3}{*}{ Day 13} & \multirow{4}{*}{$\begin{array}{r}R A R \alpha-R A \\
-M P \\
R A R \gamma-R A\end{array}$} & \multicolumn{2}{|c|}{ Period A } & \multicolumn{2}{|c|}{ Period B } & \multicolumn{2}{|c|}{ Period C } \\
\hline & & +1.49 & $P=0.40$ & & & & \\
\hline & & $-1 \cdot 14$ & $P=0.73$ & & & & \\
\hline & & $+2.77^{*}$ & $P<0.03^{*}$ & & & & \\
\hline & - MP & $+2 \cdot 17$ & $P=0.08$ & & & & \\
\hline & $\mathrm{RXR} \alpha-\mathrm{RA}$ & $+1 \cdot 19$ & $P=0.6$ & & & & \\
\hline & $-M P$ & $+1 \cdot 36$ & $P=0.33$ & & & & \\
\hline & BMP4 - RA & $+2 \cdot 84^{*}$ & $P<0.003^{*}$ & & & & \\
\hline & $-M P$ & $+2 \cdot 34^{*}$ & $P<0.03^{*}$ & & & & \\
\hline & IGF-I - RA & $-2 \cdot 18$ & $P=0.89$ & & & & \\
\hline & $-M P$ & -2.06 & $P=0.9$ & & & & \\
\hline \multirow{10}{*}{ Day 18} & $\mathrm{RAR} \alpha-\mathrm{RA}$ & +1.06 & $P=0.70$ & -1.04 & $P=094$ & & \\
\hline & $-M P$ & -1.55 & $P=0.23$ & $-3.51^{*}$ & $P<0.001^{*}$ & & \\
\hline & $R A R \gamma-R A$ & -1.04 & $P=0.83$ & +1.49 & $P=0.42$ & & \\
\hline & $-M P$ & $-1 \cdot 19$ & $P=0.74$ & -1.66 & $P=0.29$ & & \\
\hline & $\mathrm{RXR} \alpha-\mathrm{RA}$ & $+2 \cdot 88^{*}$ & $P<0.001^{*}$ & $+3 \cdot 46^{\star}$ & $P<0.05^{\star}$ & & \\
\hline & $-M P$ & $+1 \cdot 85^{\star}$ & $P<0.001^{*}$ & $+1 \cdot 19$ & $P=0.79$ & & \\
\hline & BMP4 - RA & +1.06 & $P=0.6$ & $+1 \cdot 14$ & $P=0.32$ & & \\
\hline & $-M P$ & $-1 \cdot 81^{*}$ & $P<0.001^{*}$ & $-1 \cdot 26^{\star}$ & $P<0.001^{*}$ & & \\
\hline & IGF-I - RA & -1.07 & $P=0.68$ & $+1 \cdot 43$ & $P=0.22$ & & \\
\hline & - MP & -1.54 & $P=0.35$ & $-3 \cdot 43^{\star}$ & $P<0.001^{*}$ & & \\
\hline \multirow[t]{10}{*}{ Day 23} & $\mathrm{RAR} \alpha-\mathrm{RA}$ & +1.37 & $P=0.09$ & -1.09 & $P=069$ & +1.47 & $P=0.29$ \\
\hline & $-M P$ & +1.06 & $P=0.7$ & +1.35 & $P=0.4$ & +1.49 & $P=0.26$ \\
\hline & $R A R \gamma-R A$ & $+1 \cdot 16$ & $P=0.65$ & $-1.96^{\star}$ & $P<0.001^{*}$ & $+1 \cdot 20$ & $P=0.45$ \\
\hline & $-M P$ & $+1 \cdot 13$ & $P=0.6$ & $-1 \cdot 19$ & $P=0.56$ & $+1.96^{\star}$ & $P<0.03^{*}$ \\
\hline & $\mathrm{RXR} \alpha-\mathrm{RA}$ & $+1 \cdot 12$ & $P=0.29$ & $-1.94^{\star}$ & $P<0.001^{*}$ & $+1 \cdot 21$ & $P=0.75$ \\
\hline & $-M P$ & $-1 \cdot 19$ & $P=0.4$ & $-1 \cdot 21$ & $P=0.5$ & $-2 \cdot 31^{*}$ & $P<0.03^{*}$ \\
\hline & BMP4 - RA & $+1 \cdot 50^{*}$ & $P<0.001^{*}$ & $-2 \cdot 64^{\star}$ & $P<0.001^{*}$ & $+1 \cdot 12$ & $P=0.61$ \\
\hline & - MP & $-1 \cdot 22$ & $P=0.27$ & $-2.06^{\star}$ & $\mathrm{P}<0.001^{*}$ & $-1 \cdot 16$ & $P=0.68$ \\
\hline & IGF-I - RA & $+1 \cdot 20$ & $P=0.64$ & $-1 \cdot 19$ & $P=0.74$ & +1.48 & $P=0.32$ \\
\hline & $-M P$ & $-1 \cdot 13$ & $P=0.58$ & -1.36 & $P=0.29$ & -1.07 & $P=0.72$ \\
\hline \multirow[t]{10}{*}{ Day 40} & $\mathrm{RAR} \alpha-\mathrm{RA}$ & $+3 \cdot 39^{\star}$ & $P<0.002^{*}$ & $+2.99^{\star}$ & $P<0.001^{*}$ & $+3.82^{*}$ & $P<0.001^{*}$ \\
\hline & $-M P$ & $+2.42^{*}$ & $P<0.001^{*}$ & $+7 \cdot 89^{\star}$ & $P<0.001^{*}$ & +1.47 & $P=0.36$ \\
\hline & $R A R \gamma-R A$ & $+3 \cdot 25^{\star}$ & $P<0.001^{*}$ & +1.03 & $P=0.88$ & +1.95 & $P=0.17$ \\
\hline & $-M P$ & +1.00 & $P=0.93$ & $+3 \cdot 15^{\star}$ & $P<0.001^{*}$ & -1.01 & $P=0.9$ \\
\hline & $\mathrm{RXR} \alpha-\mathrm{RA}$ & +1.34 & $P=0.22$ & $-1 \cdot 11$ & $P=0.81$ & +1.59 & $P=0.23$ \\
\hline & $-M P$ & $-1 \cdot 13$ & $P=0.34$ & $+3.58^{\star}$ & $P<0.001^{*}$ & $+1 \cdot 13$ & $P=0.56$ \\
\hline & BMP4 - RA & $+2.08^{*}$ & $P<0.02^{*}$ & $+1 \cdot 21$ & $P=0.48$ & +1.73 & $P=0.09$ \\
\hline & $-\mathrm{MP}$ & -1.09 & $P=0.73$ & $+3.44^{*}$ & $P<0.001^{*}$ & -1.03 & $P=0.84$ \\
\hline & IGF-I - RA & $+1 \cdot 26$ & $P=0.41$ & $+1 \cdot 15$ & $P=0.54$ & +1.34 & $P=0.3$ \\
\hline & - MP & $-1 \cdot 19$ & $P=0.40$ & $+2 \cdot 48$ & $P=0.1$ & -1.33 & $P=0.4$ \\
\hline
\end{tabular}

RAR, retinoic acid receptor; RXR, retinoid X receptor; BMP, bone morphogenetic protein; IGF, insulin-like growth factor. + , , positive and negative values.

* Significant variations.

For details of diets and procedures, see p. 678.

\section{Discussion}

There is currently very little information available about the effect of nutrients on morphogenesis processes in fish. Studies on mammals indicate that some nutrients act on several key genes that govern morphogenesis, such as Hox genes (Krumlauf, 1994), during specific windows of time. Based on these data, we may assume that a comparable action occurs in fish at specific periods. In mammals, studying these windows is very difficult as developmental processes occur in utero. In sea bass larvae, these developmental processes still continue after hatching, and this particularity facilitates studies of the effects of nutrition on morphogenesis, which makes this a very interesting species for developmental studies.

At $23 \mathrm{dph}$, the control group exhibited the best growth. In the MP groups, the lowest growth was observed when the MP diet was ingested during period A. We had previously demonstrated (Villeneuve et al. 2005b) that a diet containing a high percentage of EPA and DHA (4.8\%) in the phospholipid fraction did not allow optimal larval growth. The present data confirm this result and also indicate that the earlier this MP diet is ingested, the greater its negative affects upon larval growth. In the case of hypervitaminosis A, sea bass larvae growth was globally more depressed in comparison with the two other larval groups, but this reduction in growth was more pronounced during period A $(8-13 \mathrm{dph})$. At the end of the experiment (day 40), global growth followed a similar pattern to that observed at day 23 , except for surprisingly poor growth in the RA-C experimental group. This result was certainly due to factors other than nutritional conditions and might have been related to other parameters that were not monitored in this work.

During the first weeks of life, the digestion processes in marine fish larvae switch from a primary to an adult mode of digestion (Zambonino Infante \& Cahu, 2001). Some changes occur in the specific activities of pancreatic enzymes, 
(A)

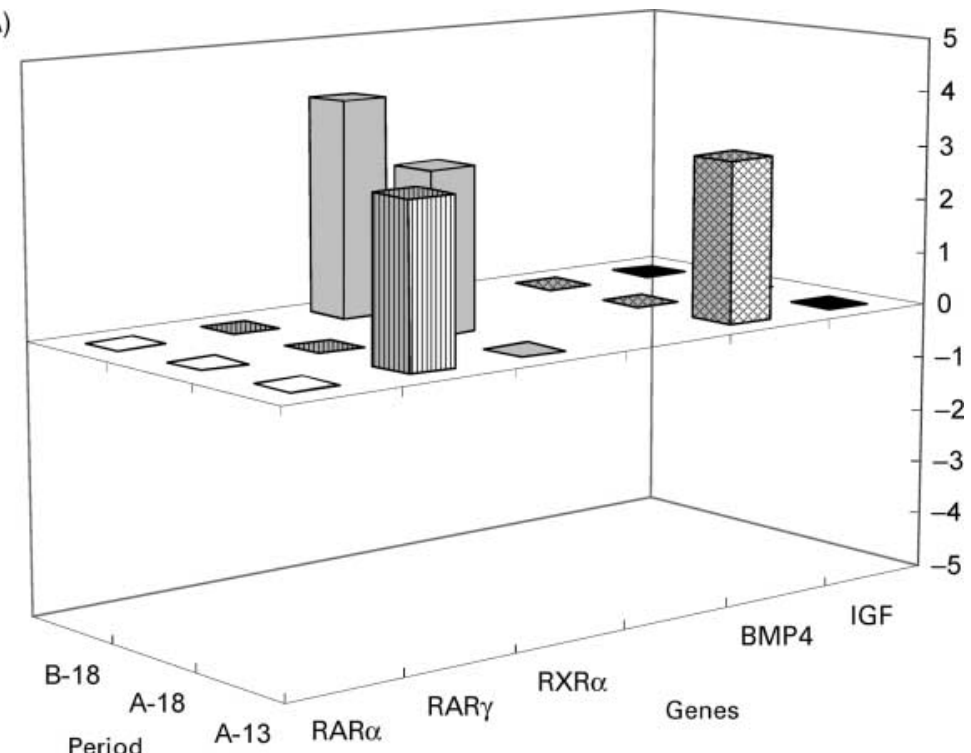

(B)

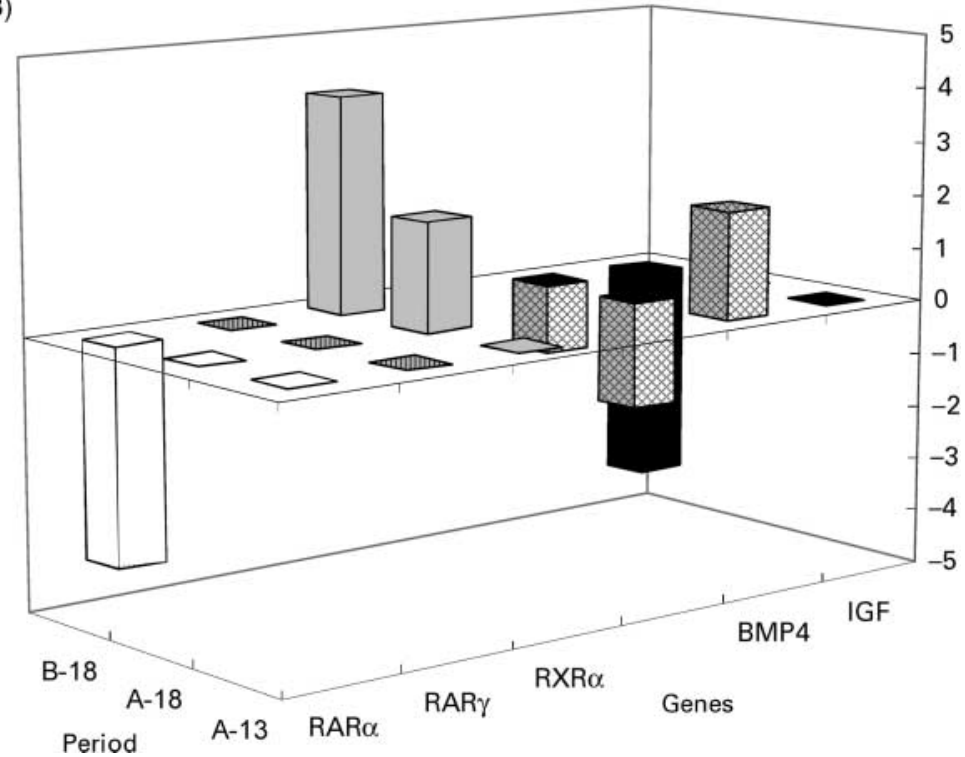

Fig. 8. Three-dimensional representations of significant up- and downregulations of gene transcription reported in Table 2 in larvae fed (A) the high-vitamin-A (RA; 7A) and (B) marine phospholipid (MP; 7B) diets, during period A (day 13 and day 18) and B (day 18). For details of diets and procedures, see. p. 678. $\square$, RAR $\alpha$;

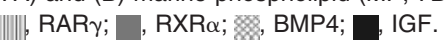

with a particularly marked decrease in amylase with age. Moreover, the pancreatic secretory function becomes progressively efficient. The maturation of intestinal cells is characterized by a reduction in cytosolic enzyme activities and a sharp increase in brush border membrane enzyme activities. Alkaline phosphatase is considered to serve as a marker for the maturation of the brush border of enterocytes: the greater its activity, the better the level of intestinal maturation (Zambonino Infante \& Cahu, 2001). Maturation of the gastrointestinal tract is normally achieved around $25 \mathrm{dph}$ in European sea bass (Zambonino Infante \& Cahu, 2001). We consequently measured specific enzymatic activities or pancreatic secretion level at this date.

In the present work, a higher level of alkaline-phosphatasespecific activity was observed in the control group, indicating that these fish exhibited the best development; in the other groups, the overall levels of alkaline phosphatase activity were in line with general growth rates. A proper development of control and MP-C larvae was also supported by the data for trypsin and amylase pancreatic secretion at day 25 , and the low level of amylase activity. In the other experimental groups, amylase specific activity was greater, suggesting a delay in maturation of the digestive tract. Previous works have shown that unbalanced diets induce a delay in digestive maturation (Ribeiro et al. 2002). This delay in maturation was always associated with a reduction in larval growth and survival, effects linked mainly to the poor digestion and metabolic use of these diets.

We observed an effect of the diet and feeding period on European sea bass morphogenesis, especially on the number 
of vertebrae. Other authors have previously reported that the number of vertebrae in fish can be influenced by factors other than nutrition, such as triploidy in trout (Kacem et al. 2004) and temperature with halibut (Lewis et al. 2004). Compared with the control group, a significant percentage of larvae exhibited the loss of one vertebra (to twenty-four vertebrae) when fed the RA diet during period A, or the development of a supernumerary vertebra (to twenty-six vertebrae) with the MP diet during the same period. In both cases, $\operatorname{RXR} \alpha$ expression increased at day 18 . We have previously demonstrated that, under optimal nutritional conditions, expression of this nuclear receptor was high during the early stages of development and then decreased as the differentiation processes came to an end (Villeneuve et al. 2004). The present data also indicated that $\mathrm{RXR} \alpha$ was highly expressed during the early stages of development, as its expression was as high in the RA-A and MP-A groups as in the controls before day 18. Afterwards, its expression was higher in the RA-A and MP-A groups than in the fish fed the control diet. This indicated that these two diets stimulated its transcription when they were distributed between 8 and $13 \mathrm{dph}$.

In fish fed diets containing an excess of retinol (RA diet), we observed an increase in RAR $\gamma$ transcription at day 13, which was probably the result of direct stimulation by retinoic acid. The literature indicates that RAR and RXR can form heterodimers and that these dimers can control the levels of transcription the receptors involved in them (Ross et al. 2000; Balmer \& Blomhoff, 2002). We can therefore hypothesize that the increased number of RAR $\gamma$ receptors at day 13 probably stimulated RXR $\alpha$ expression at day 18 . Furthermore, we demonstrated in a previous study that, in a case of hypervitaminosis A, RAR $\gamma$ was the main RAR isoform involved in the appearance of skeletal malformations that affected the cephalic region of sea bass larvae (Villeneuve et al. 2005a). The RA-A group exhibited deformities localized to the cephalic region (as mentioned earlier) as well as to the vertebral column (the loss of one vertebra).

At day 13, BMP4 expression was stimulated, and mention is made in the literature of how a synergy between BMP4 action and the retinoid pathway (Glozak \& Rogers, 1998) can lead to cellular apoptosis. This apoptosis process had been observed in embryonal carcinoma cells: in the presence of BMP4, the specific activation of RAR $\alpha$ and RAR $\gamma$ (via the presence of 9-cis retinoic acid in the culture medium) is sufficient to cause cell death (Glozak \& Rogers, 1998). It has also been demonstrated that BMP and retinoid signalling pathways could cooperate to induce the differentiation of marrow preadipocytes into osteoblasts (Skillington et al. 2002). These two types of cell probably resulted from a common precursor, located in bone marrow, that can differentiate in vitro between adipocytes and osteoblasts (Skillington et al. 2002). Indeed, under conditions leading to bone loss (for example, osteoporosis), the decreased osteoblast count correlated with increased adipocyte differentiation, suggesting that adipocytes are generated at the expense of osteoblasts.

Osteoblastic differentiation is characterized by stimulation of the expression of alkaline phosphatase (Skillington et al. 2002). In the present study, we did not observe any increase in alkaline-phosphatase-specific activity, almost certainly because of the delayed development of larvae fed RA-A. This delay was revealed by their poor intestinal maturation and their high amylase-specific activity, which should have decreased under normal conditions (Cahu \& Zambonino Infante, 2001). Taking these results together, we can hypothesize that the increase in BMP4 and RAR $\gamma$ expression reduced the number of osteoblasts available for bone formation and that this loss of bone cells was counterbalanced by pre-adipocyte differentiation into osteoblasts induced by the cooperation between retinoic acid and BMP4. These events certainly interfered with the normal process governing the differentiation of bone tissue and actively delayed it. Our hypothesis is supported by the persistence of high levels of $\mathrm{RXR} \alpha$ expression and the fact that this receptor is necessary for achieving osteoblast differentiation. Nevertheless, the reduced number of osteoblasts may have led, on one hand, to the loss of a vertebra and, on the other, to malformations affecting the cephalic region. It is interesting to note that $\mathrm{RXR} \alpha$ transcription continued to be influenced in fish fed the RA diet during period $\mathrm{B}$, but in this case it affected only the process associated with morphogenesis of the head. This suggests that, during this window of development, the genes targetted by $\mathrm{RXR} \alpha$, and involved in the formation of the vertebral column, were not subject to any other influences. It also revealed that the mechanisms of morphogenesis implicated in its formation were successfully carried out.

With regard to larvae fed the MP diet, the increased RXR $\alpha$ expression at day 18 could not be correlated with a stimulation of RAR $\gamma$ as the MP and control diets had the same vitamin A level. The MP diet contained a high level of MP with an elevated percentage of PUFA, particularly EPA and DHA (4.8\%). European sea bass larvae digest this kind of phospholipid very efficiently (Cahu et al. 2003), leading to an increased body PUFA content. These fatty acids are natural ligands for PPAR, and we assume that the excess of PUFA in the larvae stimulated PPAR expression. PPAR dimerize with $\mathrm{RXR}$, and this binding may be responsible for the high levels of RXR $\alpha$ transcription observed. Moreover, DHA is known to be an RXR ligand (Mata de Urquiza et al. 2000). Thus, the binding of DHA with RXR $\alpha$ could also be responsible for the increased transcription of $\mathrm{RXR} \alpha$ in fish fed the MP diet. At day 13, the stimulation of BMP4 expression could have amplified the osteoblast differentiation process, leading to the appearance of a supernumerary vertebra. At $18 \mathrm{dph}$, the low level of BMP4 transcription suggested that osteoblast maturation had been achieved, as it has been previously reported that BMP4 expression decreases as bone matures (Solheim, 1998). Pancreatic development markers seemed to confirm this hypothesis: the elevated secretion rate (of trypsin and amylase) revealed that the process of maturation in the exocrine pancreas in the MP-A group was comparable with that observed in the control group, whereas it was delayed in the RA-A and MP-B groups (no BMP4 stimulation being observed in these groups). Moreover, amylase-specific activity was significantly lower in the MP-A than the RA-A group.

Villeneuve et al. (2004) previously described the normal expression profile of the genes studied during the development of sea bass larvae reared under optimal nutritional conditions. They reported a global increase in RAR expression and a decrease in $\mathrm{RXR} \alpha$ transcription during larval development. In the present study, at 23 and $40 \mathrm{dph}$, the expression levels of both RAR were greater in the experimental groups than 
in the control group, whereas the expression levels of $\mathrm{RXR} \alpha$ and BMP4 were lower than in the reference group. These results suggested that normal expression tendencies, even though emphasized with regard to the control group, were again observed from day 23 and that they were also still influenced by nutritional parameters. These transcription modulations for the genes implicated in the retinoid signalling pathway had no effect on the malformation rate as the morphogenesis and cellular differentiation processes could no longer be influenced at these points.

In summary, European sea bass morphogenesis is very sensitive to vitamin A and phospholipid dietary levels during the early stages of development. The genes involved in these processes can be modulated between 8 and $13 \mathrm{dph}$, and the present results indicated that retinoid and fatty acid pathways implicated two different gene cascades. Inadequate dietary levels of vitamin A and PUFA led to different kinds of skeletal malformation. On one hand, hypervitaminosis A delayed development, reducing the number of vertebral segments and disturbing bone formation in the cephalic region, whereas on the other, an excess of PUFA accelerated osteoblast differentiation, leading to a supernumerary vertebra. These results suggest that, from a nutritional point of view, it is necessary to distinguish two larval developmental periods - before and after $13 \mathrm{dph}$ - as the composition of the diet could have a significant impact on sea bass morphogenesis before this date.

\section{Acknowledgements}

The authors wish to thank M. M. Le Gall, P. Quazuguel and $\mathrm{H}$. Le Delliou for their excellent technical assistance during larval rearing and sample analysis. L. A. N. V. and E. G. were, respectively, supported by an IFREMER-INRA grant and an EC Marie Curie Individual Fellowship (QLK-CT2001-52 009).

\section{References}

Balmer JE \& Blomhoff R (2002) Gene expression regulation by retinoic acid. J Lipid Res 43, 1773-1808.

Barnabé G, Boulineau-Coatanea F \& Rene F (1976) Chronologie de la morphogenèse chez le loup ou bar Dicentrarchus labrax (L.) (Pisces, Serranidae) obtenu par reproduction artificielle. Aquaculture 8, 351-363.

Bessey OA, Lowry OH \& Brock MJ (1946) A method for the rapid determination of alkaline phosphatase with five cubic millimeters of serum. J Biol Chem 164, 321-329.

Bradford MM (1976) A rapid and sensitive method for the quantitation of microgram quantities of protein utilizing the principle of protein-dye binding. Anal Biochem 72, 248-254.

Cahu C \& Zambonino Infante JL (2001) Substitution of live food by formulated diets in marine fish larvae. Aquaculture 200, 1-2, Special issue, $161-180$

Cahu CL, Zambonino Infante JL \& Barbosa V (2003) Effect of dietary phospholipid level and phospholipid: neutral lipid value on the development of sea bass (Dicentrarchus labrax) larvae fed a compound diet. Br J Nutr 90, 21-28.

Crane RK, Boge G \& Rigal A (1979) Isolation of brush border membranes in vesicular form from the intestinal spiral valve of the small dogfish (Scyliorhinus canicula). Biomembranes 554, 264-267.

Dagnelie P (1975) Les méthodes de l'inférence statistique. In Théorie et méthodes statistiques, pp. 1-463 [J Ducolot, editor]. Gambloux, Belgium: Les Presses Agronomiques de Gembloux.
Folch J, Lees M \& Stanley GHS (1957) A simple method for the isolation and purification of total lipids from animal tissues. J Biol Chem 226, 497-509.

Gabbitas B \& Canalis E (1997) Retinoic acid regulates the expression of insulin-like growth factors I and II in osteoblasts. J Cell Physiol 172, 253-264.

Gause WC \& Adamovicz J (1994) The use of the PCR to quantitate gene expression. PCR Methods Appl 3, 123-135.

Gisbert E, Villeneuve L, Zambonino Infante JL, Quazuguel P \& Cahu CL (2005) Dietary phospholipids are more efficient than neutral lipids for long-chain polyunsaturated fatty acid supply in European sea bass Dicentrarchus labrax larval development. Lipids 40, 609-618.

Glozak MA \& Rogers MB (1998) BMP4- and RA-induced apoptosis is mediated through the activation of retinoic acid receptor [alpha] and [gamma] in P19 embryonal carcinoma cells. Exp Cell Res 242, $165-173$.

Haga Y, Suzuki T, Kagechika H \& Takeuchi T (2003) A retinoic acid receptor-selective agonist causes jaw deformity in the Japanese flounder, Paralichthys olivaceus. Aquaculture 221, 381-392.

Haga Y, Suzuki T \& Takeuchi T (2002) Retinoic acid isomers produce malformations in postembryonic development of the Japanese flounder, Paralichthys olivaceus. Zool Sci 19, 1105-1112.

Hogan BL (1996) Bone morphogenic proteins: multifunctional regulators of vertebrate development. Gene Dev 10, 1580-1594.

Holm H, Hanssen LE, Krogdahl A \& Florholmen J (1988) High and low inhibitor soybean meals affect human duodenal proteinase activity differently: in vivo comparison with bovine serum albumin. J Nutr 118, 515-520.

Juaneda P \& Roquelin G (1985) Rapid and convenient separation of phospholipid and non phosphorus lipids from rat heart using silica cartridges. Lipids 20, 40-41.

Kacem A, Meunier FJ, Aubin J \& Haffray P (2004) Caractérisation histo-morphologique des malformations du squelette vertébral chez la truite arc-en-ciel (Oncorhynchus mykiss) après différents traitements de triploïdisation. Cybium 28, 15-23.

Keller H, Dreyer C, Medin J, Mahfoudi A, Ozato K \& Wahli W (1993) Fatty acids and retinoids control lipid metabolism through activation of peroxisome proliferator-activated receptor-retinoid $\mathrm{X}$ receptor heterodimers. PNAS 90, 2160-2164.

Krumlauf R (1994) Hox genes in vertebrate development. Cell 78, 191-201.

Lewis LM, Lall SP \& Eckhard Witten P (2004) Morphological descriptions of the early stages of spine and vertebral development in hatchery-reared larval and juvenile Atlantic halibut (Hippoglossus hippoglossus). Aquaculture 241, 47-59.

Mata de Urquiza A, S Liu, Sjöberg M, Zetterström RH, Griffiths W, Sjövall J \& Perlmann T (2000) Docosahexaenoic acid, a ligand for the retinoid X receptor in mouse brain. Science 290, 2140-2144.

Métais P \& Bieth J (1968) Détermination de l' $\alpha$-amylase par une microtechnique. Ann Biol Clin-Paris 26, 133-142.

National Research Council (1985) Guide for the Care and Use of the Laboratory Animals. Publication No. 85-23 (rev.). Bethesda, MD: National Institutes of Health.

Péres A, Zambonino Infante JL \& Cahu C (1998) Dietary regulation of activities and mRNA levels of trypsin and amylase in sea bass (Dicentrarchus labrax) larvae. Fish Physiol Biochem 19, $145-152$.

Pfaffl MW (2001) A new mathematical model for relative quantification in real-time RT-PCR. Nucleic Acids Res 29, e45.

Pfaffl MW, Horgan GW \& Dempfle L (2002) Relative expression software tool (RESTC) for group-wise comparison and statistical analysis of relative expression results in real-time PCR. Nucleic Acids Res 30, 9-36.

Ribeiro L, Zambonino Infante JL, Cahu C \& Dinis MT (2002) Digestive enzymes profile of Solea senegalensis post larvae fed Artemia and a compound diet. Fish Physiol Biochem 27, 1-2, 61-69. 
Ross SA, McCaffery PJ, Drager UC \& De Luca LM (2000) Retinoids in embryonal development. Physiol Rev 80, 1021-1054.

Sargent J, McEvoy L, Estevez A, Bell G, Bell M, Henderson J \& Tocher D (1999) Lipid nutrition of marine fish during early development: current status and future directions. Aquaculture 179, $217-229$.

Skillington J, Choy L \& Derynck R (2002) Bone morphogenetic protein and retinoic acid signaling cooperate to induce osteoblast differentiation of preadipocytes. J Cell Biol 159, 135-146.

Solheim E (1998) Growth factors in bone. Int Orthop 22, 410-416.

Suzuki T, Oohara I \& Kurokawa T (1999) Retinoic acid given at late embryonic stage depresses sonic hedgehog and Hoxd-4 expression in the pharyngeal area and induces skeletal malformation in flounder (Paralichthys olivaceus) embryos. Develop Growth Differ 41, $143-152$.

Suzuki T, Srivastava AS \& Kurokawa T (2000) Experimental induction of jaw, gill and pectoral fin malformations in Japanese flounder, Paralichthys olivaceus, larvae. Aquaculture 185, $175-187$.

Thompson DL, Gerlach-Banck LM, Barald KF \& Koenig RJ (2003) Retinoic acid repression of bone morphogenetic protein 4 in inner ear development. Mol Cell Biol 23, 2277-2286.

Villeneuve L, Gisbert E, Cahu CL, Le Gall MM \& ZamboninoInfante JL (2004) Expression and localization of some retinoid receptors during European sea bass (Dicentrarchus labrax) larvae development. Aquaculture 242, 537-551.

Villeneuve L, Gisbert E, Le Delliou H, Cahu CL \& ZamboninoInfante J (2005a) Dietary levels of all-trans retinol affect retinoid nuclear receptor expression and skeletal development in European sea bass larvae. Br J Nutr 93, 1-12.

Villeneuve L, Gisbert E, Zambonino-Infante JL, Quazuguel P \& Cahu CL (2005b) Effects of lipids on European sea bass morphogenesis: implication of retinoid receptors. Br J Nutr 94, 877-884.

Yu VC, Delsert C, Andersen B, Holloway JM, Devary OV, Näär AM, Kim SY, Boutin JM, Glass CK \& Rosenfeld MG (1991) RXR $\beta$ : a coregulator that enhances binding of retinoic acid, thyroid hormone, and vitamin D receptors to their cognate response elements. Cell 67, 1251-1266.

Zambonino Infante J \& Cahu CL (2001) Ontogeny of the gastrointestinal tract of marine fish larvae. Comp Biochem Physiol C 130, 477-487.

Zambonino-Infante JL, Cahu CL \& Péres A (1997) Partial substitution of di- and tripeptides for native protein in sea bass diet improves Dicentrarchus labrax larval development. J Nutr 127, 604-614.

Zizola CF, Balana ME, Sandoval M \& Calvo JC (2002) Changes in IGF-I receptor and IGF-I mRNA during differentiation of 3T3L1 preadipocytes. Biochimie 84, 975-980. 